\title{
Metal Industry Development in the Conditions of Formation of New Technological and Institutional Trends
}

\section{Olga Aleksandrovna Romanova and Dmitriy Vladimirovich Sirotin}

Institute of Economics, Ural Branch of RAS, Yekaterinburg, Russia

\section{Abstract}

The article emphasizes the important role of metallurgy, which in the conditions of Industry 4.0 development becomes a "fundamental" (according to the terminology of RAS academician S. Glazyev) industry, which is actively involved in the formation of the core of the sixth technological mode. The key factors of the four industrial revolutions and the corresponding production quantities in the metallurgical industry for the period from 1750 to the present time are adduced forward in the text. The trends in the development of the world ferrous metallurgy are analyzed, which made it possible to formulate the latest technological and institutional tendencies in the development of the

Corresponding Author: Olga Aleksandrovna Romanova econ@uran.ru

Received: 5 February 2019

Accepted: 6 March 2019

Published: 17 March 2019

Publishing services provided by Knowledge

(c) Olga Aleksandrovna

Romanova and Dmitriy

Vladimirovich Sirotin. This article

is distributed under the terms of the Creative Commons

Attribution License, which permits unrestricted use and redistribution provided that the original author and source are credited

Selection and Peer-review under the responsibility of the NIOKR-2018 Conference Committee. industry. It is demonstrated that metallurgical production in Russia, in spite of lagging behind in many respects, for example, labor productivity, sorting efficiency, etc. from the metallurgy of developed countries, still has sufficient potential for the introduction of the latest technological solutions here, including in the field of information technology. An assessment of the digitization of the metallurgical industry of Russia on the basis of a set of reasonable indicators is brought up in the present work. The importance of the strategic areas is also justified for the development of metallurgy, such as the control of electricity consumption and energy costs, the introduction of effective recovery strategies and the improvement of work safety of the workers, which corresponds to the solution of the most important task - the production of "environmentally friendly metals" (Green Metals). The development of the metallurgical complex of the Sverdlovsk region for the period from 2008 to 2016 is analyzed in details. It is proved that the region has all the necessary prerequisites for the development of modern technological areas here. The possibility of changing the specialization of the region in the direction toward the development of additive production is shown. The main features of the new technological image of metallurgy of the Sverdlovsk region are formed.

Keywords: metallurgy, Industry 4.0, technological and institutional trends, digitalization, metallurgical complex of the Sverdlovsk region

\section{Introduction}

Modern metallurgical production is a complex industry, the reproduction of which G OPEN ACCESS 
depends on the metal-consuming sectors and reacts to all fluctuations in these industries. The most important condition for its successful development at the global, national and regional levels is an ability to meet the needs of the market with high-quality metal products in a timely manner.

Nowadays, the promotion of technological innovation is a determining factor in maintaining the competitiveness of metallurgy in the global market. The long-term technical and economic development of the economy is inextricably linked with the introduction of technological, organizational and marketing innovations in all sectors of the real economy. Their well-coordinated work predetermines the successful implementation of the development strategy for the domestic industry based on the principles of Industry 4.0. At the same time, the position of the "carrier" industry, in the interpretation of Academician Glazyev, the development of which is necessary for the formation of the core of the sixth technological mode, is incurred by metallurgy. The key moments of the metallurgy development amid the industrial revolutions are presented in Figure 1.

The main condition for maintaining the competitiveness of metal products under Industry 4.0 is constant innovation, and the main factor of production is knowledge. The priority areas for investment are human capital and environmental safety of production. The constant growth of the requirements for the quality of metal products acts as a driving force for improving the manufacturing process. Insufficiently high rates of technological development of ferrous metallurgy increase the risks and vulnerability of the industry in the construction materials market.

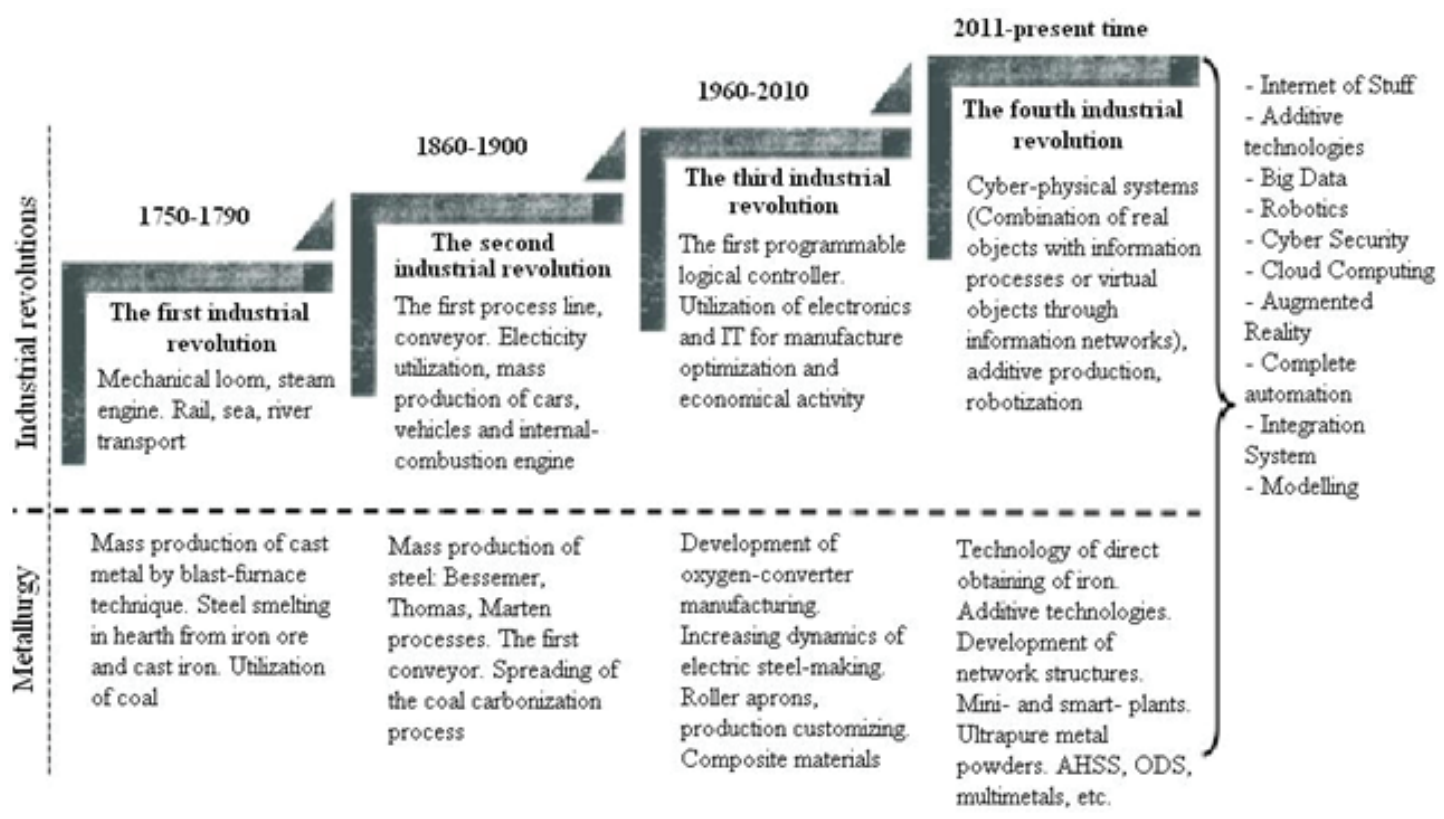

Figure 1: Metallurgy development within the framework of the industrial revolution. (Note: AHSS - Advanced High-Strength Steels; ODS - Oxide Dispersion Strengthened steel.) 
According to the World Steel Association (WSA), in 2017, 1 billion 689.4 million tons of steel were produced worldwide, which is $3.8 \%$ more than in the previous year (Table 1). China still holds the leading position in terms of steel production - 831.7 million tons, Japan is in second place - 104.7 million tons, followed by India (101.4 million tons), USA (81.6 million tons) and Russia (71.3 million tons).

TABLE 1: Top 10 countries leading in steel production, MM tons [1].

Country
China
Japan
India
US
Russia
South Korea
Germany
Turkey
Brazil
Italy
Total
production
worldwide

\begin{tabular}{|c|c|c|}
\hline \multicolumn{3}{|c|}{ Production } \\
\hline $\mathbf{2 0 1 7}$ & $\mathbf{2 0 1 6}$ & Growth rate (\%) \\
\hline 831.7 & 786.9 & 5.7 \\
\hline 104.7 & 104.8 & -0.1 \\
\hline 101.4 & 95.5 & 6.2 \\
\hline 81.6 & 78.5 & 4 \\
\hline 71.3 & 70.5 & 1.3 \\
\hline 71.1 & 68.6 & 3.7 \\
\hline 43.4 & 42.1 & 3.5 \\
\hline 37.5 & 33.2 & 13.1 \\
\hline 34.4 & 31.3 & 9.9 \\
\hline 24 & 23.4 & 2.9 \\
\hline 1689.4 & 1627 & 3.8 \\
\hline
\end{tabular}

\begin{tabular}{|c|c|c|}
\hline \multicolumn{3}{|c|}{ Consumption } \\
\hline 2017 & $\mathbf{2 0 1 6}$ & Growth rate (\%) \\
\hline 736.8 & 680.3 & 8.3 \\
\hline 64.4 & 62.2 & 3.5 \\
\hline 87.2 & 83.6 & 4.3 \\
\hline 97.7 & 91.9 & 6.3 \\
\hline 40.6 & 38.6 & 5.2 \\
\hline 56.4 & 57.1 & -1.3 \\
\hline 41.8 & 40.5 & 3.2 \\
\hline 36.1 & 34.1 & 5.9 \\
\hline 19.2 & 18.2 & 5.5 \\
\hline 24.5 & 24.1 & 1.7 \\
\hline 1587.4 & 1516 & 4.7 \\
\hline
\end{tabular}

The share of Asian countries today accounts for about $69 \%$ of smelted steel in total. Among them, India shows high growth rates and surpassed the amount of 100 million tons in 2017. In the country, large investment projects are being implemented for the construction of new and expansion of existing production capacities. Japan is the only state among the leaders in Table 1 showing a decrease of steel production in 2017. At the same time, in Japan the demand in the high-tech segment of the market is increased - in the automobile industry, for rolled sheets made of high-strength steel (UHSS category). The leader of metallurgical production, China, showed a slightly lower growth rate than India in 2017. China is also actively involved in processes of innovation and renovation of fixed assets.

The output growth of Chinese steel smelting was caused, among other things, by increasing domestic demand. Over the past year, the consumption of steel products in China increased by $8.3 \%$ reaching almost 737 million tons. The growth of the steel consumption is also observed in the USA, Turkey and Brazil by more than 5\% in 2017. In 2017, the average value of steel consumption growth in the world was $4.7 \%$ in comparison with 2016. 
In the long run, the global steel consumption is expected to grow 1.5 times by 2050 . It is related to various factors including the increase of steel consumption in traditional and new sectors of the economy and growth of consumption in emerging markets (India, Iran), and with the difficulty of substituting steel with alternative materials. The need of the key sectors of the EU economy in metal products by the 2050 year takes into account [2]:

- transport - multimetals, hybrid metal, non-metal materials, combined heatresistant metals; SMART;

- energy - austenitic, single-crystal and dispersion-strengthened (ODS) steel; reinforced and composite metals; metals with heat-shielding coating, etc.;

- construction - fire-resistant steel, damping materials (for example, Fe-Al-Si alloys), composites.

Further growth in the demand of the real economy in ferrous metals is associated with new directions for the development of material production. In China for instance, as part of the industry development program "China Manufacturing 2025", by 2020 and 2025, have been highlighted key areas for the development of new materials [3]:

- new advanced materials - for 3D printing, powdered ferroalloys, high-temperature powdered alloys;

- key strategic materials - special anti-corrosion steel with supercritical temperature $\left(700^{\circ} \mathrm{C}\right)$, single-crystal alloys in the form of powder, cheap high-temperature alloys;

- advanced base metals - high-strength automotive steel, heavy-duty steel for highspeed rail tracks, high quality steel for offshore structures, functional composite construction steel of the new generation; pipeline steel, including the one for transportation of oil and gas products: ultra-high strength steel (x 90/100), steel with thickness more than $33 \mathrm{~mm}$ (x 80); roll-bonded clad plates, stainless ultrastrong steel.

As of today, no key changes in the ferrous metal production processes are expected, the traditional steel production scheme will remain unchanged. Nevertheless, as world experience shows, the most significant innovations for the industry are implemented through new approaches applied in materials science. For example, in the recent years, the field of advanced high-strength steels (AHSS) production has been developing rapidly. By 2025, as European experts predict, the demand for AHSS will double the level of 2015 [4]. Consumer properties of this steel are characterized by the fact that it is $30 \%$ lighter and five times stronger than other materials serving similar purposes. 
According to the experts, at least $80 \%$ of the innovative developments are based on the introduction of new materials and on the technologies for their production $[5,6]$. An increased application of the nanotechnologies to an industrial scale is expected, which will jolt the further development of powder metallurgy, plasma spraying and the artificial formation of ultrapure metals. Also, today it is impossible to talk about any modern samples of industrial products without metals with controlled properties. In the world, mainly in developed economies, the trend of production customization is getting established, and at that the need for new types of high and super high quality steel increases according to the customer demands.

The analysis of global ferrous metallurgy tendencies makes it possible to point out the following basic conditions:

- growth in labor productivity and operational efficiency, mainly due to new technologies (IT integration, 3D printing, energy and resource saving) and modernization of existing ones;

- the growth of the share of innovative products mainly due to the release of new types of high-strength steel and additional service properties, and the development of precision technologies;

- an increase of attention to environmental friendliness of production, the growth of environmental innovations (electric arc furnace, direct intermediate technologies, waste-free production) $[4,6,7]$.

These data form an idea of the fundamental changes that are awaiting the metallurgical industry in the conditions of the Industry 4.0 development. These changes are based on the advancement of both technological and organizational innovations. Their significance increases under the digital economy parameter influence forming a new infrastructure of the production process based on cyber-physical systems.

In terms of basic indicators, European metallurgy exceeds the Russian one on average by $60-70 \%$. Nevertheless, in the Russian economy, metallurgy remains one of the leading industries. Over the past few decades, there have been many changes in all sub-sectors of the domestic ferrous metallurgy. After 2009, there are no sharp jumps in the dynamics of steel-making production (Figure 2).

The average coefficient of fixed assets deterioration of domestic metallurgy was estimated at $\sim 46.6 \%$ in 2015 [8]. The number of employed in metallurgy 1,258 thousand people in 2000 was, by 2017 this number dropped to almost 700 thousand people. The level of per capita consumption of steel in Russia approached the indicators of developed countries (USA, EU, etc.). In 2015, according to the WSA, metal consumption 


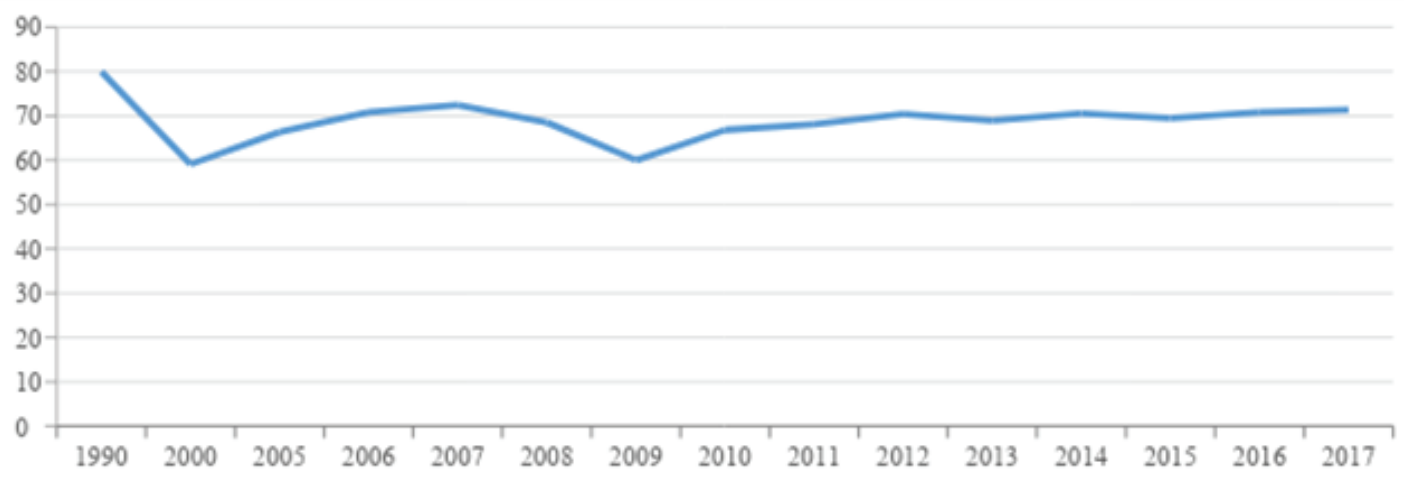

Figure 2: Dynamics of steel production in Russia, MM tons [1].

per capita in Russia was $274.8 \mathrm{~kg}$, in the USA - $298.8 \mathrm{~kg}$, in the EU - $306 \mathrm{~kg}$. In Russia, this indicator should reach the mark of $390 \mathrm{~kg}$ by 2020 [9]. This indicates the possibilities of economic growth at the achieved level of metal consumption [10]. More than $80 \%$ of the metal consumed in Russia is accounted for by machine building, the construction sector, the pipe industry, etc. (Figure 3) [11].

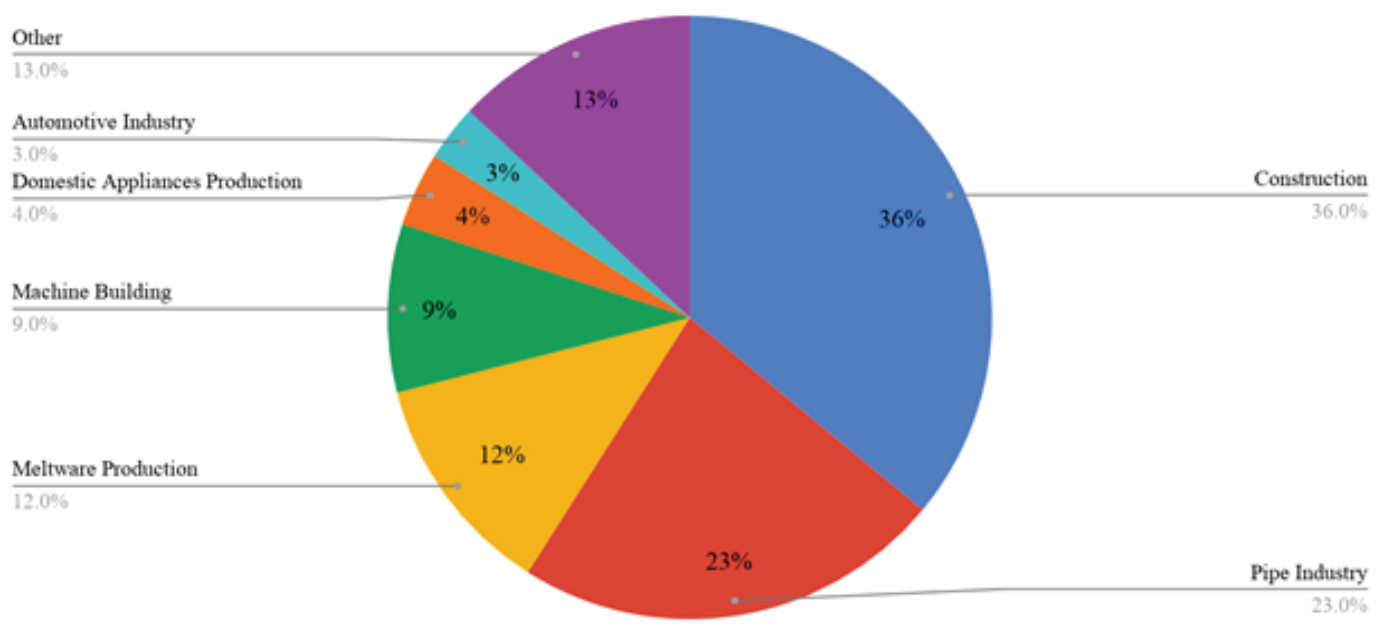

Figure 3: Structure of metal consumption in Russia, \% $[8,12]$.

Forming strategic materials for the development of ferrous metallurgy, alternative options are considered for using the latest technological solutions to reduce the development lag of ferrous metallurgy of the Russian Federation. At the present moment, this lag of the industry remains in terms of technological efficiency, labor productivity and product range efficiency [13]. The reason for the lag in the level of labor productivity is not only the technological factor but also the sociopolitical factor determining the social responsibility of large enterprises, the need to resolve the problems of single-industry towns, and insufficiently effective production management. 
In accordance with the forecast for the development of the domestic economy until 2020, the rise in demand for metals estimated at around 3-5\% per year [14]. Herewith, the need for high-quality metal products increases. In a long-term perspective, the domestic consumption of stainless steel is expected to increase up to 200 thousand tons by 2020 and up to 800 thousand tons by 2030 . Such a forecast relies on the expected development programs of consumer industries to be implemented during this period.

Industry 4.0 assumes the integration of the production assets of enterprises, which are involved in all stages of creation of the product value into a single digital ecosystem. At the same time, the maximum effect depends on the organization degree of the ways of receiving, processing and exchanging data based on the tools of Industry 4.0 and digitalization. A major role in the process of digitization of production is played by the introduction of automatic resource management systems associated with the Internet of Things technology, Big Data and cloud services through intelligent sensors that transmit the full amount of microdata about production processes. This will be facilitated by involvement of skilled specialists, increasing the availability of special software, the introduction and development of CRM, ERP, SCM systems, databases, computing power, spreading cloud services technologies, etc. As a result of the digitization process, the expected changes in the industry include a significant increase in labor productivity, production efficiency and sales of metal products, reduction of transaction costs, growth of innovative activity and quality of metal products both for specific and general purposes.

The development of metallurgy in a direction towards the formation of the digital economy is based on the promotion of digital technologies among the enterprises and their active use. The metallurgical industry digitalization in the Russian Federation can be assessed by the set of indicators presented in the Figure 4 . The given list of indicators takes into account the key elements of the digital economy.

For the last year, there is a positive trend of growth for all indicators analyzed here. As shown in the Figure 4, the highest rates are typical for cloud services. Also, there is an increase in the amount of main systems used in the domestic metallurgical enterprises for purchasing and sales management of goods, works, services, as well as CRM-, ERP-, SCM automation systems. In general, the development of the main elements of the digital economy within the metallurgy is traced at the federal level.

One of the largest territories of metallurgical production placement in the Russian Federation is the Ural region, and in particular, the Sverdlovsk region. The share of metallurgy in the GRP of the Sverdlovsk region is about 13\% [16, p. 84]. Regarding the volume of production shipped from the manufacturing industries, according to the Federal State 


\section{CRM-, ERP-, SCM - systems}

\section{Cloud services}

Access to the datadases with use of global networks

Autimized production management

\section{Mangament of services, purchases and sales}

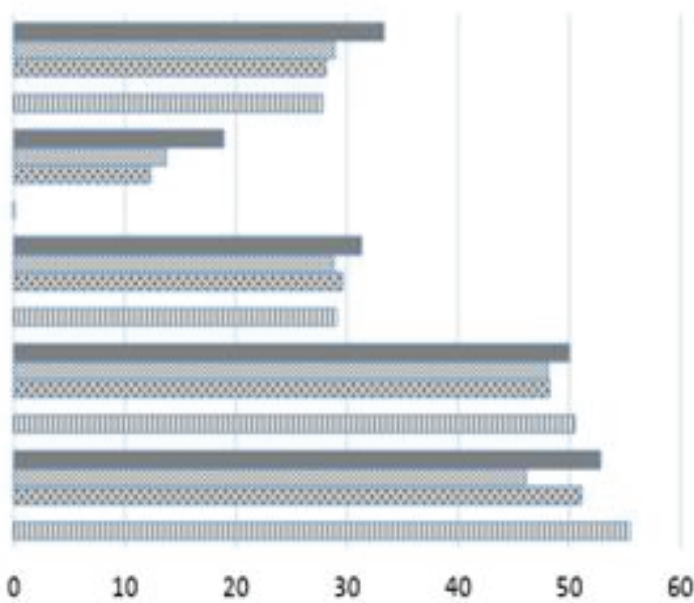

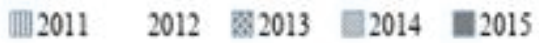

Figure 4: The use of ICT and special software in organizations by type of activity - Metallurgical production and production of finished metal products, \% of the total number of organizations in the Russian Federation [15].

Statistics Service of the Sverdlovsk Region, the share of metallurgy decreased over the last year by $7.8 \%$, reaching $49.7 \%$ in 2016 . This is due not so much to the reduction in the manufacturing volumes of metallurgical products but rather to the increase in the production of other processing activities (food production, electrical equipment, vehicles, chemical production, etc.). According to Sverdlovskstat, at the end of 2016, the share of metallurgy in the average number of employees and the share of investment in fixed assets from all types of economic activity amounted to $7.2 \%$ and $16.6 \%$, respectively (Table 2).

TABLE 2: The role of metallurgy in the economy of the Sverdlovsk region, \%.

\begin{tabular}{|c|c|c|c|c|c|c|c|c|c|}
\hline \multirow[t]{2}{*}{ Indicator } & \multicolumn{9}{|c|}{ Year } \\
\hline & 2008 & 2009 & 2010 & 2011 & 2012 & 2013 & 2014 & 2015 & 2016 \\
\hline Share in GRP & 13.5 & 13.4 & 13.2 & 13 & 12.9 & 12.8 & 13.2 & $\mathrm{n} / \mathrm{d}$ & $\mathrm{n} / \mathrm{d}$ \\
\hline $\begin{array}{l}\text { Share in the volume of goods } \\
\text { shipped from the } \\
\text { manufacturing industries }\end{array}$ & 59.4 & 54.6 & 56.5 & 58.9 & 55.9 & 54.3 & 55.5 & 57.5 & 49.7 \\
\hline $\begin{array}{l}\text { Share in investments in fixed } \\
\text { assets }\end{array}$ & 25.6 & 19.3 & 11.8 & 12 & 8.6 & 8.9 & 11.8 & 11.4 & 16.6 \\
\hline $\begin{array}{l}\text { Share in the average number } \\
\text { of employees }\end{array}$ & 11.8 & 7.6 & 7.5 & 7.6 & 7.7 & 7.4 & 7.2 & 7.1 & 7.2 \\
\hline
\end{tabular}

For a more complete analysis of the industry development in the region, beside the traditional indicators, it is also advisable to take into account factors characterizing the qualification level of labor resources, the degree of compliance of technological development with world trends, innovation and other significant indicators (Table 3). 
At the end of 2016, the volume of investments in fixed assets of enterprises from the metallurgical complex amounted to 38.5 billion rubles. The value of labor productivity (as a ratio of the volume of products shipped to the total number of people employed in the metallurgy) decreased slightly in 2016, but remained at a relatively high level - 7.5 million per rubles/person. The share of metallurgical production organizations implementing technological innovations in 2016 was 16.1\%. From the Table 3 it follows that in recent years there has been a decrease in the share of intermediate metal products. This is mainly due to the growth in the production of low value-added metal products for the construction sector, which became more in demand for the region during this period.

At the same time, there was also a decrease in demand from 2014 to 2016 for welded pipes of the oil and gas pipeline and a less noticeable increase in the demand of the same market segment for seamless pipes.

In 2016, there was an increase in harmful emissions into the air and into the water, which was basically related to the production activities of the Nizhny Tagil Metallurgical Works.

In general, the positive trends in the development of metallurgy in the Sverdlovsk region include: productivity growth helped by an increase in investment in fixed assets; reducing the load on the environment as well as the energy and resource intensity of the production of finished steel; growth in the share of innovative products; maintaining the qualification level of employees among those employed in the industry; and an increase in the share of steel production in electric furnaces which exceeds the average Russian level.

Today, as part of the development of the industrial complex, individual elements of Industry 4.0 are being formed in the region. In 2016, the Governor of the Sverdlovsk Region, together with the management of PJSC "Engineering Works named after M.I. Kalinin", Rostech State Corporation, JSC "Science and Innovations" and UrFU, signed an agreement on the creation in the field of the research and production consortium "Additive Technologies". The project also involves: JSC "Ural Electrochemical Plant" ("UEKhK", Novouralsk); PJSC VSMPO-AVISMA Corporation (Verkhnaya Salda); PJSC "AllRussian Institute of Light Alloys" (“VILS, Moscow”); Experimental Design Bureau "Novator"

named after Lulyev L.V. (Yekaterinburg); Ural Branch of the Russian Academy of Sciences. The consortium is planning to implement investment projects to create powderlayer fusion units as well as to obtain metal powders by gas atomization [17]. Currently, the Urals Consortium is developing a regulatory framework including the creation of passports for metallic materials used in 3D printing. 
TABLE 3: Dynamics of economic development indicators of the Sverdlovsk region by type of activity: Metallurgical production and production of finished metal products, and technical and economic indicators of the development of ferrous metallurgy of the Sverdlovsk region (according to statistical catalogs of the Federal State Statistics Service of the Sverdlovsk region and materials of the journal Bulletin Ferrous metallurgy for 2013-2017).

\begin{tabular}{|c|c|c|c|c|c|}
\hline \multirow[t]{2}{*}{ Indicator } & \multicolumn{5}{|c|}{ Year } \\
\hline & 2012 & 2013 & 2014 & 2015 & 2016 \\
\hline \multicolumn{6}{|c|}{ Metallurgical Production and Production of Finished Metal Products } \\
\hline $\begin{array}{l}\text { Amount of own production shipped goods } \\
\text { and performed works, billion rubles }\end{array}$ & 677.9 & 682.8 & 745 & 877.8 & 805.2 \\
\hline Investment in fixed assets, MM rub. & 23937 & 23806 & 30169 & 28240.5 & $\begin{array}{l}38518 \\
\text { The }\end{array}$ \\
\hline $\begin{array}{l}\text { Average annual number of employees, } \\
\text { thousand people. }\end{array}$ & 119.5 & 119.3 & 113.6 & 108.9 & 106.9 \\
\hline Labor productivity, mln rubles/person & 5.67 & 5.72 & 6.56 & 8.06 & 7.53 \\
\hline $\begin{array}{l}\text { Volumes of polluting emissions into the } \\
\text { atmosphere, thousand tons. }\end{array}$ & 259.1 & 258.4 & 242.8 & 235.2 & 237.6 \\
\hline $\begin{array}{l}\text { Contribution to the pollution of water bodies } \\
\text { surface, million cu. } \mathrm{m} \text {. }\end{array}$ & 104.34 & 101.3 & 100.25 & 98.25 & 102 \\
\hline $\begin{array}{l}\text { The share of innovative products in the } \\
\text { industry, } \%\end{array}$ & 2.32 & 3.97 & 3.96 & 8 & 9.1 \\
\hline Technological innovation costs, MM rub. & 8683.1 & 7819.1 & 10812 & 15876.3 & 24095.1 \\
\hline $\begin{array}{l}\text { Degree of amortization of the fixed assets at } \\
\text { the end of the year,\% }\end{array}$ & 39.7 & 45.6 & 47.6 & 47.1 & 46.7 \\
\hline $\begin{array}{l}\text { Export volume of metals and metal } \\
\text { products, MM USD }\end{array}$ & $4,608,7$ & 3876.8 & 4266 & 3136.6 & 3236.3 \\
\hline $\begin{array}{l}\text { The share of qualified employees from the } \\
\text { total number of employees, } \%\end{array}$ & 75.9 & 75 & 75.2 & 73.5 & 76.9 \\
\hline $\begin{array}{l}\text { The share of highly qualified specialists in } \\
\text { the number of qualified employees, } \%\end{array}$ & 28.3 & 34.6 & 32,1 & 32.7 & 32.2 \\
\hline \multicolumn{6}{|l|}{ Including Ferrous Metallurgy } \\
\hline $\begin{array}{l}\text { Finished iron and steel goods manufactured } \\
\text { per year, tons }\end{array}$ & 14403 & 14044 & 13663 & 13566.5 & 13612.9 \\
\hline $\begin{array}{l}\text { Share of steel production in the electric } \\
\text { furnaces, } \%\end{array}$ & 48.07 & 47.99 & 48.77 & 48.35 & 49.23 \\
\hline Share of high-value added steel products, \% & 17,25 & 17.41 & 16.59 & 15.28 & 15.05 \\
\hline Resource consumption of rolled steel, $\mathrm{kg} / \mathrm{t}$ & 1131.4 & 1125 & 1116.5 & 1129 & 1128.2 \\
\hline $\begin{array}{l}\text { Specific power consumption of rolled steel } \\
\text { products, e.u.f. } \mathrm{kg} / \mathrm{t} \text { (equivalent unit of fuel) }\end{array}$ & 690 & 675 & 660 & 707,5 & 670 \\
\hline
\end{tabular}

The State Scientific Center of the Russian Federation JSC NPO TsNIITMASH (Moscow) is currently engaged in the development of two-powder, two-laser additive devices based on SLM technology that allows printing stainless steel parts. The production launch of such machines is planned at the Ural Electrochemical Plant in the period from 2018 to 2019.

The enterprise NPO "Centrotech" (Novouralsk, Sverdlovsk region) is implementing a project to develop plants for the production of metal powders. The customers of 
the project are PJSC United Aircraft Building Corporation, PJSC ODK-Saturn (Yaroslavl Region) and PJSC ODK-Aviadvigatel (Perm). Among the interesting projects one should also highlight the work of the Regional Engineering Center UrFU, which is developing modular industrial 3D printers based on SLM technology. CJSC "Micromet" (Verkhnyaya Salda) produces metal powders based mainly on titanium alloys and has manufacturing capacities to output up to 395 tons of powder per year. On the basis of the produced powders, the company manufactures 3D products and also is building additional capacities on the territory of the special economic zone "Titanium Valley". Customers of CJSC "Micromet" are mainly enterprises of the military-industrial complex.

On the territory of the Sverdlovsk region, industrial 3D-printers also operate at the Ural Optical Mechanical Plant named after E.S. Yalamov ("UOMZ", Yekaterinburg) and FSUE Production Association "October" (Kamensk-Uralsky) [18].

Analysis of the industry development trends at the global, national and regional levels, the evaluation of forecast data and reports from international consulting companies working in the field of metallurgy development, allowed identifying new trends determining the further technological development of the industry in the digital economy:

- the growth of consumer demands for quality of the metal on a set of properties including those with a precision character;

- a fundamentally new level of automation of metallurgical production systems and services providing it;

- the increasing importance of taking into account the flexibility of strategic decisions at choosing perspective technologies and their resource support;

- development and expansion of the functionality of additive technologies of metallurgical production based on ultra-pure metal powders;

- consolidation of digital technologies in the chain of creation of value-added metal product cost.

The implementation of new technological capabilities of the metallurgical industry is possible on the basis of modern institutional transformations including:

- the development of network structures that contribute to the formation of conditions for increasing the efficiency of enterprises of the mining and metallurgical complex under the conditions of Industry 4.0;

- the development of mini and smart metallurgical plants;

- transition to new business models that meet the conditions for the development of Industry 4.0; 
- the formation of new development institutions that promote the implementation of the principles of Industry 4.0 in metallurgy, which develop additive technologies, the Internet of Things, Big Data, production robotization;

- expansion of basic tools for the development of metallurgy by more active use of tools for venture financing;

- development of public, educational and scientific institutes for the development of metallurgy, ensuring the improvement of the qualification level of labor resources, strengthening project innovation activities, taking into account social needs.

Promotion of the advancement of new technological solutions in metallurgy should increase the role of interaction between government agencies, business and science, and the development of international relations [19]. At the federal and regional levels, support for enterprises in the industrial complex of the region is provided by the largest development institutions today.

Against the background of these trends, the foundations of a new image of the region's metallurgy are being formed. Its main features take into account the creation of products that have the characteristics of the highest world level; continuous development of scientific and technical potential with increased attention to the problem of energy and resource conservation as well as environmental friendliness of production; development of core technology competencies within Industry 4.0; increasing the importance of labor competence; provision of innovation infrastructure, development of digitalization technologies: Internet of Things, Big Data; local approximation to the final consumers, but not fully dependent on them; use of advanced IR technologies, almost complete automation of production processes; provision of production with main types of natural resources; development of additive technologies.

Results of the industry development assessment allowed establishing the presence of preconditions indicating the real possibilities of forming in the long term a new technological image of the metallurgical complex of the Sverdlovsk region. This is facilitated by the presence of a serious scientific and technological potential provided by the labor base with a significant share of highly qualified specialists. Favorable geographical location of the Urals helps to strengthen and expand business connections. The readiness for digitization of metallurgy in the region is justified by the presence at the enterprises of a complex of automated planning systems, networking technologies that form a new understanding of business models. The advancement of additive technologies in the region forms the basis for the development of new priority high-tech metal products markets in the future. The resource, production, technological and personnel potential 
accumulated by the metallurgical complex of the Sverdlovsk Region forms a sufficiently strong base for further development under the conditions of Industry 4.0. In this case, the determining resource is the Person, his creativity and entrepreneurial activity. The importance of using such traditional resources as mineral and raw materials, scientific and technological, industrial, institutional does not lose its significance. However, the requirements for the quality of traditional resources are changing dramatically, with considerable attention to the possibilities of changing the combination of used resources. Such a combination allows increasing the "potential of recombination" and contributes to the formation of high-quality metallurgy of the Urals, which implements the principles of Industry 4.0 in its development.

The article was prepared with a support of the RFBR grant No. 18-29-24027 "The investigation of physical-chemical characteristics of man-made wastes of ferroalloy production and development of technical-economical principles for their effective and ecologically safe processing".

\section{References}

[1] World Steel in Figures. World Steel Association. Belgium. 2018. 17 pp. https://www.worldsteel.org/en/dam/jcr:f9359dff-9546-4d6b-bed0-996201185b12/ World+Steel+in+Figures+2018.pdf (accessed: 18/06/2018).

[2] The EU steel industry. European Commission. http://ec.europa.eu/growth/sectors/ raw-materials/industries/metals/steel/ (accessed: 02/19/2018).

[3] China Manufacturing 2025. Putting the Ahead of Market Forces. 2017 by the European Union Chamber of Commerce in China. http://www.iberchina.org/files/ 2017/china_industry_2025.pdf (Revised: 02/14/2018).

[4] Abey Abraham. Metallic Material Trends in North American Light Vehicles. Ducker Worldwide. 13 May 2015. URL: https://www.autosteel.org/-/media/files/autosteel/ great-designs-in-steel/gdis-2015/track-2---abraham.ashx (accessed: 20/02/2018).

[5] Kablov, E.N. (2012). VIAM: 80 years of scientific creativity and achievements. Modern materials - the basis of innovative modernization of Russia. Metals of Eurasia, no.3, pp.10-15.

[6] Budanov I.A., Terentyev N.E. (2017). Problems and directions of technological modernization of the metallurgical complex of Russia in the context of "green" economic growth. Proceedings: Institute of National Economic Forecasting of the Russian Academy of Sciences, no.15, pp.76-91. 
[7] Global trends affecting the development of the steel industry. Analytical report. Astana: JSC "Kazakhstan Institute of Industry Development" ("KIDI", JSC). URL: http: //kidi.gov.kz/docs/otchety/5531319.pdf (accessed: 21/05/2018).

[8] RosStat. (2016). Industrial production of Russia - 2016. Moscow: RosStat.

[9] Zhigir, I. (2015). New times for the steel industry: a step forward or backward? Metal supply and sales, no.1, pp.10-17.

[10] Budanov, I.A. (2016). The development of metallurgy depends on the transition of the Russian economy to the model of investment growth. Steel, no.6, pp.82-89.

[11] Valyaykina,T.P. and Boboshko, D.Yu. (2016). Prospects for import substitution in ferrous metallurgy of the Russian Federation. Steel, no. 3, pp.62-65.

[12] Ustinov, V.S. (2012). Analysis of the consumption of metal products in the machinebuilding complex of Russia. Proceedings: Institute of Economic Forecasting of the Russian Academy of Sciences. vol. 10, pp. 280-301.

[13] Budanov, I.A. and Ustinov, V.S. (2015). Innovation-investment processes of development of metallurgical production in Russia. Proceedings: Institute of Economic Forecasting of the Russian Academy of Sciences, no.13, pp.324-347.

[14] Semin, A. (2017). Advance development of the production of high-quality steel - a state priority in the field of metallurgy. Metals of Eurasia, no.4, pp.14-15.

[15] Abdrakhmanova, G.I., et al. (2017). Digital Economy Indicators 2017: statistical compilation. Moscow: HSE.

[16] Tatarkin A.I., et al. (2017). Ural vector of innovative development of the Russian metallurgy. EKO, no.3, pp.79-97.

[17] Official site of the administration of the Governor of the Sverdlovsk region. http:// gubernator96.ru/news/show/id/4320 The date of circulation 13.03.2018

[18] Additive technologies may become a new production specialization of the Sverdlovsk region. Site of the Government of the Sverdlovsk region. http://www-new. midural.ru/news/list/document98468/ (accessed 03/03/2018).

[19] Tsyb, S. (2017). Priority tasks of the metallurgical complex from the point of view of the state industrial policy at the present stage. Metals of Eurasia, no.4, pp.4-5. 